\title{
REACH THE STARS: HOW TO MANAGE HUMAN RESOURCES SUCCESSFULLY IN EARLY CHILDHOOD EDUCATION CENTER?
}

\author{
Ajeng Regita Maudy, Misno A. Lathif, Senny Weyara Dienda Saputri \\ Universitas Jember \\ Corresponding e-mail: senny.fkip@unej.ac.id
}

\begin{abstract}
This research is motivated by the success of the PAUD Terpadu Al Furqan Jember in developing students' potential, academic, and non-academic achievements. This success cannot be separated from human resource management, especially teachers as educators. This study aimed to determine the process of human resource management for teaching staff at PAUD Terpadu Al Furqan Jember. This type of research is descriptive qualitative with observation, interviews, and documentation as data collection methods. The results showed that the human resource management process in PAUD Terpadu Al Furqan Jember was carried out in planning, organizing, developing, and evaluating. The planning stage began with a needs analysis by the principal, followed by recruitment by the foundation. The principal's organizing stage is carried out by coordinating human resources' placement according to expertise and the appointment of a companion teacher to assist the apprenticeship program for new teachers. Schools and foundations carry out the development stage in competency improvement and quality control activities, routinely held every Saturday. The evaluation phase is carried out once a week after development activities and at the end of each semester carried out by the principal, peers, and parents. The evaluation results' follow-up is the existence of coaching carried out by the foundation and the school in constructive personal criticism, followed by training attended by all human resources.
\end{abstract}

Keywords : human resource management, teacher management, early childhood education center

\begin{abstract}
Abstrak
Penelitian ini dilatarbelakangi oleh keberhasilan PAUD Terpadu Al Furqan Jember dalam mengembangkan potensi dan prestasi akademik maupun non-akademik peserta didik. Keberhasilan ini tidak lepas dari manajemen sumber daya manusia, terutama guru sebagai tenaga pendidik. Tujuan penelitian ini adalah mengetahui proses manajemen sumber daya manusia untuk tenaga pendidik di PAUD Terpadu Al Furqan Jember. Jenis penelitian ini adalah deskriptif kualitatif dengan observasi, wawancara, dan dokumentasi sebagai metode pengumpulan data. Hasil penelitian menunjukkan bahwa proses manajemen sumber daya manusia di PAUD Terpadu Al Furqan Jember dilakukan dengan tahapan perencanaan, pengorganisasian, pengembangan, dan evaluasi. Tahap perencanaan dimulai dengan analisis kebutuhan oleh Kepala Sekolah, dilanjutkan rekrutmen oleh Yayasan. Tahap pengorganisasian dilakukan oleh kepala sekolah dengan mengkoordinasikan penempatan SDM sesuai keahlian, dan penunjukan guru pendamping untuk mendampingi program magang bagi guru baru. Tahap pengembangan dilakukan oleh sekolah dan Yayasan berupa kegiatan peningkatan kompetensi dan kendali mutu yang rutin diselenggarakan setiap hari Sabtu. Tahap evaluasi dilaksanakan seminggu sekali setelah kegiatan pengembangan dan setiap akhir semester yang dilakukan oleh kepala sekolah, teman sejawat, serta wali murid. Tindak lanjut dari hasil evaluasi yaitu adanya pembinaan yang dilakukan oleh pihak Yayasan dan sekolah dalam bentuk kritik membangun secara personal, kemudian dilanjut dengan pelatihan yang diikuti oleh seluruh SDM.
\end{abstract}

Keywords : manajemen sumber daya manusia, manajemen guru, pendidikan anak usia dini 


\section{Introduction}

Early Childhood Education Center (ECEC) has an important role in building a nation's character (Sujiono \& Sujiono, 2012). Referring to Minister of Education Act No 146 of 2014 concerning the 2013 Curriculum for Early Childhood Education, ECEC aims to optimize children's growth and development as a foundation for children's readiness to take the next education step. ECEC provides stimulus, guidance, nurturing, and learning to produce children's skills and abilities in six development areas. For this reason, ECEC needs to design an environment under the child's developmental stages to provide space for children to explore, observe, imitate, and experiment (Sujiono \& Sujiono, 2012). Thus children can build their knowledge as active learners through their interactions with the environment.

Implementing an education can be influenced by the teacher's role (Maiza \& Nurhafizah, 2019). ECEC management is needed to manage the quality of the institution. Good human resources can only be created through quality education. Therefore, ECEC management is needed to fix obstacles in implementing learning in ECEC (Ridho, Markhamah; \& Darsinah, 2017). Learning in ECEC must be oriented towards child development so that teachers are expected to create a safe, comfortable learning environment and design learning that can stimulate children's development (Hernawati, 2013).

Early childhood has different characteristics, abilities, attitudes, and behaviours according to the development stage in their age group and each child's uniqueness (Khairi, 2018). Therefore, it is necessary to have human resources capable of optimizing all aspects of child development and their unique potential as a whole. Human resource management in schools is essential to prepare educators who have competence in learning in ECEC (Bachtiar, 2016).

Human resource management in schools is a strategic activity because it uses various policies to achieve school goals (Mukminin, Habibi, Prasojo, \& Yuliana, 2019). Thus, human resource management has a contribution to determining the future of an institution or organization. Human resource management is expected to make qualified educators and plan, organize, develop, and evaluate educators in an educational institution (Mukminin et al., 2019).

Facing the community and the environment around which is continually changing, institutions need to evaluate the strategies, policies, and programs that will be developed and make significant improvements. Educational institutions must be able to provide support for human resource management practices precisely, effectively, and efficiently so that educators can make a useful contribution. The strategies provided by educational institutions must also be in line with the objectives and provide support for the development of teaching staff because the teaching staff is an asset of an institution to achieve its goals (Khoirunnisa, 2018). 
Based on the results of preliminary observations and interviews conducted in August 2019, PAUD Terpadu Al Furqan Jember carried out human resource management stages to ensure students' education was following the level of development and characteristics of the child, as well as ensuring the quality of human resources. This condition is evidenced by an HR development schedule that is routinely carried out every Saturday to honour teachers' competence properly. Teachers can also guide students to have potential and achievements following the interests of the children's talents. The academic field's potential and achievements and non-academic fields include memorizing the Koran, dancing skills, and selfdefence skills.

From these preliminary data, it appears that teachers' role in PAUD Terpadu Al Furqan Jember supports the quality of education services provided by schools to students. Students at PAUD Terpadu Al Furqan can develop and increase their potential through quality education services, both in the academic and non-academic fields. According to (Rohmat, 2017), teachers' success in carrying out their roles is inseparable from the management of human resources carried out by schools, where PAUD Terpadu Al Furqan Jember from the start focused its human resource management on the ability of educators to provide services to early age students. Therefore, this study investigates human resource management carried out by PAUD Terpadu Al Furqan Jember.

This research is focused at the organizational level, including investigations on planning, management, development, and evaluation of human resources in PAUD Terpadu Al Furqan Jember, especially for educators. This research's main objective is to describe the teaching staff's human resource management at PAUD Terpadu Al Furqan Jember.

\section{Method}

The research was conducted at PAUD Terpadu Al Furqan Kabupaten Jember, the time of the research was started from 2-23 December 2019 with 4 days of observation, 5 days of interview and 1 day to adapt to the school environment. The research subjects were school principals and teachers from each age level, starting with toddlers in daycare, Play Group, Kindergarten Group A, and Group B. This type of research is descriptive qualitative. The methods used for data collection are observation, interviews, and documentation.

Observation is carried out by participating in schools' activities, but it cannot be followed for some activities because it is institutional privacy and secret. Interviews in this study were conducted with school principals and teachers from each age level, starting from Day Care for toddlers, Play Group, Kindergarten Group A and, Group B. This study did not have access to interviews with the foundation office. The 
documentation obtained in this study were school profiles, biodata of principals and teachers, development documents, photos of development activities, and work meeting activities. This research did not get access to permission from the foundation's management for planning documents, organising documents, and evaluation documents. Data analysis was performed using interactive methods (Miles \& Huberman, 1994), namely data reduction, data display and conclusions drawing and verification.

\section{Results and Discussion}

The following shows data retrieval results from human resource management at PAUD Terpadu Al Furqan Jember through the planning, organizing, development, and evaluation stages.

\section{Planning}

Based on the results of the interview, it can be concluded that the planning process begins with a needs analysis conducted by the principal by looking at the number of students, the number of teachers addressed in the class table, and working hours. After the principal's needs analysis has been completed, the ECEC unit submits a letter made by the school administration service through an oral order from the school principal to the foundation for acquiring new human resources. The foundation conducts recruitment by distributing notifications to social media and individuals or teachers who work in the ECEC unit. Once the application is entered, the foundation is selected by holding an interview test and a reciting Koran test. All tests are carried out in one full day. Those who pass the selection will be contacted by the foundation and receive a letter of assignment to be submitted to the ECEC unit. The letter is received by the school administration service and gives to the principal, then the principal notifies the job placement, gets a partner teacher, and conducts a trial period of 6 months. The decision to become permanent employees is based on evaluations and assessments carried out by all human resources in ECEC. This condition is based on the results of an interview with the principal who said:

"It is the responsibility of the unit when conducting trials for the prospective teacher. The first trial was for 3 months by understanding the tasks, after the first 3 months of promotion, followed by the next 3 months. Then it is analyzed, and then it is decided whether the HR is fit to be a permanent employee or not. "(Interview, 21 December 2019)

Teacher recruitment planning aims to obtain professional teachers according to educational institutions' qualifications, to improve education quality (Isnaini, 2015). Professional early childhood educators can be assessed from educators' academic qualifications (Marienda, Zainuddin, \& Nuriyah, 2012). According to research conducted by (Cikita, 2018), educators need to know early childhood education and child characteristics. Recruitment of teachers is carried out by identifying and 
analyzing needs in the school; then, the benefits of the planning process can be felt, and the goals of an institution can be achieved. PAUD Terpadu Al Furqan Jember conducts recruitment by looking at the results of analysis information related to the job specifications needed and the conditions given to new employees. This condition happened because there was no special team to carry out the planning process from the school itself. According to (Hasibuan, 2016) steps in planning include the use of information results from the analysis results that can help describe work.

\section{Organizing}

Based on the interview results, it can be concluded that the organizing process in the PAUD Terpadu Al Furqan Jember is carried out by the school principal, assisted by the head of the unit and the respective coordinator. Organizing new teachers or internships is carried out by the coordinator, where the internship teacher is located. The internship teacher will receive a guide from a senior teacher during the trial period, and the senior teacher is tasked with informing the tasks that must be done and the rules in the classroom. The senior teacher is appointed directly by the principal. The senior teacher will report to the teacher coordinator regarding the internship teacher's performance during the first trial period, 3 months. After that, the coordinator reports to the principal about the performance, attitudes (Kanan, 2020).

Organizing for the school activity program is carried out by the curriculum coordinator, human resource coordinator, and student coordinator who receives direct orders from the school principal via oral in a coordination meeting which is held once a month and is usually done when there are essential things that need to be discussed and negotiated immediately. After the design of activities and themes for the new school year is completed, the results obtained are immediately reported to the principal, if the principal agrees, it will be communicated to the teacher and employees. Organizing school programs serve to direct and achieve goals through the available resources (Nur, Harun, \& Ibrahim, 2016). For the selection of the head of the committee for the implementation of the activities, the principal will be appointed directly by seeing the abilities they have such as being responsible, being able to lead peers, being creative, being able to work together, and being willing to listen to and receive opinions or suggestions from others, and to have selfmotivation. According to their expertise and experience and not having double positions, educators' placement will improve an organization's performance (Suyatni, Suib, \& Syukri, 2015).

For internship teacher who is still in the trial period, they cannot take a turn to become chairman of the committee, because schools do not know for sure their abilities or expertise, responsibility, and honesty. So, internship teachers only help 
prepare for needs, decorations, and timing of activities. This condition is concluded from the results of an interview with the principal who said,

"When organizing new staff or teaching staff, the principal will place his position following the needs analysis at the beginning of the planning. The school principal is also assisted by the head of the unit and their respective coordinators to provide supervision and knowledge of their school obligations. As well as being able to receive the same rights as employees or other educators, internship teachers or new teachers cannot be appointed or elected as committee chairman in activities scheduled by the school because they do not know how to behave honestly and responsibly. " (interviewed 21 December 2019)

According to (Ulfatin \& Triwiyanto, 2016), organizing or empowerment must aim to make decisions in planning so that the program can be carried out correctly, obtain maximum results and have a sense of responsibility for the decisions made. PAUD Terpadu Al Furqan conducts organizing by the principal of all existing human resources and is assisted by the structural. This condition is following the results of research which state that the organization of learning programs is carried out by the agreement and arranged under the vision, mission, and needs of ECEC (Suyatni et al., 2015), and carried out following the tasks given in the organizational structure (Fitriani, 2015). Organizing is also carried out in three stages, starting with the principal's decision to give human resources with creative or innovative ideas so that schools provide good services to the community. The presence of a coordinator meeting evidence to discuss learning themes and activities that the school will implement in the next year. If seen directly by the principal, the second stage opens and permits all human resources to participate in development activities outside of school. This condition supports the research conducted by (Manda, 2016) who concluded that organizing is needed to improve skills in carrying out the tasks given. The third stage regarding the responsibilities and benefits of all former and current human resources is the same. However, for new human resources, it needs guidance and assistance to carry out their responsibilities properly, and new human resources or internship teachers cannot yet become committee heads in implementing school activities.

The conclusion is that the school has interpreted the meaning of organizing or empowering school programs to direct and achieve goals through available sources (Nur et al., 2016). This condition is evidenced by the plan for an activity program that will be carried out in the next year and the committee chairman's election based on the sense of responsibility they have and teachers' daily attitudes. Schools also place human resources following the teacher's field of expertise. Also, in selecting the head of the committee for the school activity program, the principal chooses objectively 
according to the results of daily class assessments, communication with children and peers so that teachers who are truly capable and creative will be selected.

\section{Development}

Based on the interviews' results regarding the development process, it can be concluded that the foundation and the school have programmed the human resource development process. Human resource development with the foundation is carried out once a month. The foundation's development was attended by all units ranging from Play Group, Kindergarten, Primary School, Secondary School, High School, and Vocational School. According to their school fields, foundation development activities with quality control are carried out by grouping teachers, for example, administration, classroom teachers, and class teachers. Each of them is a speaker about what will be discussed in developing quality from the small groups. The speakers are chairman of the foundation member board (Amalia \& Martani, 2013).

The development program aims to gain knowledge and skills in ECEC learning so that educators can carry out learning activities in schools sekolah (Hayati, Pamungkas, \& Syamsudin, 2015). There are models of development that exist in school, namely internal, external, and individual development. Internal development is usually more occasional, such as there will be supervision from the main office, Surabaya. External development, namely sending human resources to attend training, seminars, and workshops outside of school (Anwar, 2011). Human resources are also appointed directly by the principal based on needs, loyalty, and family permission. This condition is the same as the results of research conducted by (Sakban, Nurmal, \& Ridwan, 2019) regarding school principals' policies that provide opportunities for teachers to take part in training organized by the government or other institutions. Individual development is carried out of their own will because they are not appointed by the school principal or sent by the school. This data is obtained from a part of interviews with the principal who said,

" There is a training and coaching program for teachers which is held once a week." (interview, 21 December 2019).

This compulsory training program applies to all teachers related to applied learning, for example, BCCT training and K13 curriculum training. Besides, there are training programs within or outside of school that is followed by appointed teachers according to school needs. This data is concluded from the results of the teacher interview as follows,

" There, at that time, BCCT training, curriculum training that was followed by all teachers. There is training that is only attended by a few teachers that are based on the teachers' needs, especially teachers who are structural." (Interview with teacher A on 9 December 2019) 
" There, K13 curriculum training by inviting speakers from Al Falah. Quality development with participant coordinators." (Interview with teacher B on 11 December 2019)

In theory, human resource development, according to (Sutrisno, 2009) development is a way of helping institutions to prepare a quality workforce following the strategies that have been prepared. In PAUD Terpadu Al Furqan Jember has implemented human resource development following the theory, evidenced by the school's development schedule and implemented every Saturday. New HR or internship teachers and development are given to senior HR or permanent teachers. This condition follows the research conducted by (Abroza, 2015) that training must be carried out for all human resources available at the school. Because with the ECEC development and training program, it is hoped that educators will develop competence and understanding in the learning process in ECEC (Yulianti, 2019).

\section{Evaluation}

Based on the interview results, it can be concluded that the school principal, peers, and parents carried out the evaluation process. Routine personal evaluation is carried out every Saturday after the completion of HR development activities. Peer evaluations are usually seen from their daily lives at school and by checking the paper, including teacher competence indicators. Peer assessments are conducted at the end of the semester, and 3 colleagues assess at least one teacher. The evaluation is carried out by the parents at the end of the semester using an application that has been provided by the school. Evaluation of school principals is carried out through supervision at the end of the semester. Due to many human resources, the principal school forms a special supervision team with one of its members taking from the curriculum coordinator oleh (Pranita, Kurniah, \& Suprapti, 2018). One of the ways to improve the quality of schools is to supervise human resources in schools. In this study, the principal assessed or evaluated human resources' performance from the supervision team results and from the results of daily assessments such as discipline in coming to school. Supervision helps improve and enhance schools' learning processes related to improving communication and improving teachers' professional and personal (Nofpriyaldi \& Rifma, 2016). The principal assessed the supervision team when the supervision team assessed all human resources. The supervision process is reflected, among others, in interviews with teachers as follows:

"From the supervision per semester, the teacher performance assessment from parents, then peers. Supervision is a team, not only the principal." (Interview with teacher B on 11 December 2020)

Apart from the routine evaluation, an annual evaluation is also carried out, which is part of the school year's annual work meeting. The evaluation is submitted by the HR coordinator, as illustrated in the observation note as follows: 
... The first working meeting discussed the overall evaluation delivered by the HR coordinator and the activity coordinator. ... This activity discusses all the results of each teacher's assessment regarding the performance for one year and what activities have been carried out well.

"(Observation note of the meeting activity on December 16, 2019)

The follow-up model of the evaluation results is coaching from the principal assisted by the coordinator by calling the parties concerned to come to the principal's office to talk about performance and attitudes that need improvement. This condition follows the research conducted by (Iskandar, 2013), which states that the HR performance evaluation results are used as material to direct, guide, and further manage HR. Coaching is also carried out from the foundation, which is constructive criticism so that the coached teachers can improve their better performance and attitudes. Coaching from the foundation is the last alternative when the school's coaching does not respond accordingly and adequately. So the school principal will ask for help from the foundation by calling the section that handles HR so that coaching is carried out. After that, the foundation will give a letter to the teacher to come to the foundation office. All human resources will receive guidance from schools and foundations but have different points of emphasis. This data was obtained from the results of an interview with the principal who said,

"'The evaluation is carried out in three ways: the principal, peers, and guardians of the students. Both principals and peers, both in terms of teacher performance and service, discipline, communication, and work ethic, become involved in the teacher's personality and professionalism. " (interviewed December 21, 2019)

In theory, according to (Rismawati dan Mattalata, 2018), evaluation is carried out systematically to find out whether teacher performance is following institutional standards or not. Finding from the research results of the PAUD Terpadu Al Furqan Jember, the evaluation has been carried out systematically; this is evidenced by the existence of duties or responsibilities given to teachers and all human resources to assess peers, the supervision team, and the existence of coaching. Given the evaluation results that have been obtained. Besides, the evaluation process has professional and bureaucratic goals (Ulfatin \& Triwiyanto, 2016). The purpose of professional evaluation emphasizes employees' involvement in organizing professional standards to be assessed, and the objectives of bureaucratic evaluation emphasize design, implementation, and how to conduct the evaluation that is carried out. The overall evaluation objective is to determine and measure each activity program (Munthe, 2015). In PAUD Terpadu Al Furqan Jember carry out two evaluation objectives when viewed from the way the evaluation is carried out once a week on Saturdays and is included in the performance appraisal based on indicators that must be owned by professional teachers. Other researchers argue that teachers 
or lecturers' professionalism can also be seen from the implementation of teaching, research, and community service (Sasono, 2014). So it can be concluded that the evaluation carried out in schools is nothing but to provide input or coaching so that teachers' competence and expertise can increase and develop properly. The school implements an evaluation at the end of the semester from the principal, peers, parents, and the school principal's supervision team.

This study's limitations are that the researchers have not had access to direct interviews with the foundation, the limited time for data collection is allowed by the school, do not obtain permission to attend meetings, and access school-owned HR management documents.

\section{Conclusion}

Human resource management for teaching staff at PAUD Terpadu Al Furqan Jember takes place to plan, organize, develop, and evaluate. In the implementation of the first stage, namely planning, the school has carried out a needs analysis process by the principal by looking at the number of students, the number of teachers addressed on the class table, and working hours. If there is a need for human resources, the school submits a letter to the foundation's recruitment process. The second stage is organizing, which is carried out by the school principal in supervising and giving orders for the preparation of activity programs and learning themes and coordinating the placement of human resources. Furthermore, the principal is assisted by the unit's head and their respective coordinators for organizing new teachers or internships. The internship teacher will receive a companion teacher during the trial period. The third stage is development carried out by schools and foundations. The development carried out by the foundation is carried out once a month, and the development carried out by the school is routine once a week on Saturdays. Development in schools is more focused on developing creativity and morals, while development at foundations is more focused on improving teacher competency skills and quality control. The last stage is evaluation, in which the school evaluates once a week after completion of development activities and at the end of each semester carried out by the school principal, peers, and guardians of students. The follow-up to the evaluation results is the guidance carried out by the foundation and the school. Coaching is carried out in the form of constructive criticism personally with the human resources concerned, then in the form of training attended by all existing human resources.

Human resource management at PAUD Terpadu Al Furqan Jember is carried out with the stages of planning, organizing, developing, and evaluating which schools should consider related to the critical priority time management and teacher workload be optimized. Schools can also hold training or workshops related to 
effective and efficient time management methods to build motivation for educators' performance.

\section{References}

Abroza, A. (2015). Strategi Pengembangan Sumber Daya Manusia Meningkatkan Keunggulan Kompetitif (Studi Kasus di Pondok Pesantren Hidayatullah Balikpapan). Universitas Islam Negeri Maulana Malik Ibrahim Malang.

Amalia, M., \& Martani, W. (2013). Pelatihan Penyusunan Program Pembelajaran Pendidikan Karakter Anak Usia Dini Pada Guru Tk. HUMANITAS: Indonesian Psychological Journal, 10(2), 13. http:/ / doi.org/10.26555/humanitas.v10i2.333

Anwar, K. (2011). Jaminan Mutu dan Upaya Pengembangan Profesionalitas Guru Pada Abad Pengetahuan. Nur El-Islam, 2(2), 88-105.

Bachtiar, M. Y. (2016). Pendidik Dan Tenaga Kependidikan. Jurnal Publikasi Pendidikan, 6(3), 196-202. http:/ / doi.org/10.26858/publikan.v6i3.2275

Cikita, N. P. (2018). Studi Kualifikasi Akademik Guru Taman Kanak-Kanak Sekecamatan Srandakan Kabupaten Bantul, 658-667.

Fitriani, A. N. (2015). Pengelolaan Program Pendidikan Anak Usia Dini (PAUD) Di Taman Penitipan Anak (TPA) Dharma Wanita Persatuan (DWP) Rumah Sakit Umum Pusat (RSUP) Dr. Sardjito Yogyakarta. Skripsi. Universitas Negeri Yogyakarta.

Hasibuan, M. S. P. (2016). Manajemen sumber daya manusia edisi revisi. Jakarta: PT Bumi Aksara.

Hayati, N., Pamungkas, J., \& Syamsudin, A. (2015). Pelatihan Pengelolaan Paud Di Padukuhan Sekitar Universitas Negeri Yogyakarta. Jurnal Pendidikan Anak, 4(1), 548-556. http://doi.org/10.21831/jpa.v4i1.12343

Hernawati. (2013). Proses Pembelajaran Anak Usia Dini Berorientasi Perkembangan (Studi Kasus di Kelompok Bermain Negeri Pembina Ciatrip dan Kelompok Bermain AL Biruni Cerdas Mulia Kota Bandung). Jurnal Penelitian Pendidikan, 16(2), 110-118.

Iskandar, U. (2013). Kepemimpinan Kepala Sekolah Dalam Peningkatan Kinerja Guru. Jurnal Visi Ilmu Pendidikan, 10(1), 1018-1027. http:/ / doi.org/10.26418/jvip.v10i1.2061

Isnaini, R. L. (2015). Implementasi Rekrutmen Guru Disd Ta'Mirul Islam Surakarta (Kajian Manajemen Sumber Daya Manusia Di Sd Islam). Jurnal Pendidikan Agama Islam, 12(1), 109-120. http:/ / doi.org/10.14421/jpai.2015.121-08

Kanan, S. L. (2020). Manajemen Tenaga Guru Di SMP Negeri 1 Lintang Kanan. Jurnal Manajer Pendidikan, 14(1), 66-80.

Khairi, H. (2018). Karakteristik Perkembangan Anak Usia Dini dari 0-6 Tahun. Jurnal Warna, 2(2), 15-28.

Khoirunnisa. (2018). Manajemen Sumber Daya Manusia (MSDM) Pada Lembaga Pendidikan. An-Nuha, 5(2), 209-230. 
Maiza, Z., \& Nurhafizah, N. (2019). Pengembangan Keprofesian Berkelanjutan dalam Meningkatkan Profesionalisme Guru Pendidikan Anak Usia Dini. Jurnal Obsesi : Jurnal Pendidikan Anak Usia Dini, 3(2), 356. http:/ / doi.org/10.31004/obsesi.v3i2.196

Manda, M. (2016). Fungsi Pengorganisasian dan Evaluasi Peserta Didik. Kelola: Journal of Islamic Education Management, 1(1), 89-101. http:/ / doi.org/10.24256/kelola.v1i1.432

Marienda, W., Zainuddin, M., \& Nuriyah, E. (2012). Kompetensi Dan Profesionalisme Guru Pendidikan Anak Usia Dini. Jurnal Visi Ilmu Pendidikan, 1(1), 147-156. http:// doi.org/10.26418/jvip.v1i1.42

Miles, M. B., \& Huberman, M. a. (1994). Qualitative data analysis: An expanded sourcebook. Evaluation and Program Planning. http://doi.org/10.1016/01497189(96)88232-2

Mukminin, A., Habibi, A., Prasojo, L. D., \& Yuliana, L. (2019). Manajemen sumber daya manusia dalam pendidikan. Yogyakarta: UNY Press.

Munthe, A. P. (2015). PENTINGYA EVALUASI PROGRAM DI INSTITUSI PENDIDIKAN: Sebuah Pengantar, Pengertian, Tujuan dan Manfaat. Scholaria: Jurnal Pendidikan Dan Kebudayaan, 1. http:/ / doi.org/10.24246/j.scholaria.2015.v5.i2.p1-14

Nofpriyaldi, \& Rifma. (2016). Persepsi Guru Tentang Proses Supervisi Kepala Sekolah di SMK N 1 Payakumbuh. Jurnal Bahana Manajemen Pendidikan, 8(C), 36.

Nur, M., Harun, C. Z., \& Ibrahim, S. (2016). Pendidikan Pada Sdn Dayah Guci Kabupaten Pidie. Jurnal Administrasi Pendidikan, 4(1), 93-103.

Pranita, U., Kurniah, N., \& Suprapti, A. (2018). Supervisi Klinis Kepala Sekolah Pendidikan Anak Usia Dini Islam Terpadu Auladuna Kota Bengkulu. Jurnal Ilmiah Potensia, 3(1), 54-65.

Ridho, R., Markhamah; \& Darsinah. (2017). Pengelolaan Pembelajaran Paud. Wacana Didaktika, 5(2), 189. http:/ / doi.org/10.31102/ wacanadidaktika.v5i02.63

Rismawati dan Mattalata. (2018). Evaluasi Kinerja: Penilaian Kinerja Atas Dasar Prestasi Kerja Berorientasi Kedepan. Makassar: Celebes Media Perkasa.

Rohmat. (2017). Manajemen Pendidikan Anak Usia Dini. YINYANG: Jurnal Studi Islam, Gender Dan Anak, 299-325. http:/ / doi.org/10.24090/yinyang.v12i2.2017.pp299-325

Sakban, Nurmal, I., \& Ridwan, R. bin. (2019). Manajemen sumber daya manusia. Alignment: Journal of Administration and Educational Management, 2(1), 2019. http:/ / doi.org/10.22201/fq.18708404e.2004.3.66178

Sasono, E. (2014). Manajemen sumber daya manusia perguruan tinggi; tantangan dan kebutuhan. Jurnal STIE Semarang, 6(2), 64-76.

Sujiono, Y. N., \& Sujiono, B. (2012). Konsep Dasar Pendidikan Anak Usia Dini. Jakarta: PT Indeks. 
Sutrisno, E. (2009). Manajemen sumber daya manusia. Jakarta: Kencana.

Suyatni, S., Suib, M., \& Syukri, M. (2015). Pengelolaan Program Pendidikan Anak Usia Dini pada Kelompok Bermain. Jurnal Pendidikan Dan Pembelajaran Katulistiwa, 4(8), 11.

Ulfatin, N., \& Triwiyanto, T. (2016). Manajemen sumber daya manusia bidang pendidikan. Depok: PT Rajagrafindo Persada.

Yulianti, D. (2019). Pengembangan Profesionalisme Guru Pada Mata Pelajaran yang DIUN-KAN di Madrasah Tsanawiyah (MTS) Nurul Ummah Kota Gede Daerah Istimewa Yogyakarta. skripsi. Universitas Negeri Yogyakarta. 